\title{
Wheat Virus Identification Within Infected Tissue Using Nanopore Sequencing Technology
}

\author{
John P. Fellers, ${ }^{1, \dagger}$ Christian Webb, ${ }^{2}$ Madison C. Fellers, ${ }^{1}$ Jessica Shoup Rupp, ${ }^{2}$ Erick De Wolf ${ }^{2}$ \\ ${ }^{1}$ USDA-ARS, Hard Winter Wheat Genetic Resistance Unit, Manhattan, KS 66506 \\ ${ }^{2}$ Kansas State University, Department of Plant Pathology, Manhattan, KS 66506
}

\begin{abstract}
Viral diseases are a limiting factor to wheat production. Viruses are difficult to diagnose in the early stages of disease development and are often confused with nutrient deficiencies or other abiotic problems. Immunological methods are useful to identify viruses, but specific antibodies may not be available or require high virus titer for detection. In 2015 and 2017, wheat plants containing Wheat streak mosaic virus (WSMV) resistance gene, Wsm2, were found to have symptoms characteristic of WSMV. Serologically, WSMV was detected in all four samples. Additionally, High Plains wheat mosaic virus (HPWMoV) was also detected in one of the samples. Barley yellow dwarf virus (BYDV) was not de-

time-consuming and expensive. Subsequently, cDNA from infected wheat tissue was sequenced with single-strand, Oxford Nanopore sequencing technology (ONT). ONT was able to confirm the presence of WSMV. Additionally, TriMV was found in all of the samples and BYDV in three of the samples. Deep coverage sequencing of full-length, singlestrand WSMV revealed variation compared with the WSMV Sidney-81 reference strain and may represent new variants which overcome Wsm2. These results demonstrate that ONT can more accurately identify causal virus agents and has sufficient resolution to provide evidence of causal variants.
\end{abstract} tected, and a detection kit was not readily available for Triticum mosaic virus (TriMV). Initially, cDNA cloning and Sanger sequencing were used to determine the presence of WSMV; however, the process was
Keywords: wheat streak mosaic virus, Triticum mosaic virus, barley yellow dwarf virus, nanopore sequencing, plant disease diagnostics
Crops are faced with many biotic stresses from germination to harvest, and producers need accurate pathogen identification in order to implement management strategies. Disease diagnosis is often based on visual assessments; however, abiotic stressors, caused by soil chemical toxicity, nutrient deficiency, heat, and/or drought stress can mimic disease phenotypes. Plant viruses are especially difficult to diagnose based on visual symptoms alone. In most cases, diagnosis is verified using an antigen-based or a PCR assay (Price et al. 2010). Antigen assays can determine the major virus present in a sample but cannot identify specific variants. PCR can identify specific single nucleotide polymorphisms (SNPs) present in the virus population, but PCR is limited to a small region of the genome, nucleotide extraction methods, primer sequences, and detection techniques. PCR results will also be skewed toward the dominant virus genotype within the population.

Accurate virus identification and classification can now take advantage of genomics and molecular biology. However, the protocols, investment of equipment, and supporting chemistry can be costly. In the past, an unknown virus could be sequenced by first purifying one of the viral proteins, amino acid sequencing, and reverse

\section{${ }^{\dagger}$ Corresponding author: J. Fellers; john.fellers@ars.usda.gov}

Disclaimer: Mention of trade names or commercial products in this publication is solely for the purpose of providing specific information and does not imply recommendation or endorsement by the U.S. Department of Agriculture. USDA is an equal opportunity provider and employer.

This publication is a joint submission of the U.S. Department of Agriculture and the Kansas Experiment Station, publication number 19-059-J.

*The $\boldsymbol{e}$-Xtra logo stands for "electronic extra" and indicates that two supplementary figures and one supplementary table are published online.

The author(s) declare no conflict of interest.

Accepted for publication 5 February 2019.

This article is in the public domain and not copyrightable. It may be freely reprinted with customary crediting of the source. The American Phytopathological Society, 2019. translation to design PCR primers. The virus would then be subcloned into parts, sequenced by di-deoxinucleotide (Sanger)-based sequencing, and assembled into a contiguous sequence (Seifers et al. 2008; Tatineni et al. 2009). This approach is very time-consuming, requiring various techniques to obtain full-length genome sequence. Next generation sequencing provides a means of sequencing viral nucleotide strands directly. One of the most popular is Illumina Biotechnology's pyrosequencing (San Diego, CA), which provides accurate, but short, $\sim 75-250$ base pair $(\mathrm{bp})$ reads of cDNA or genomic DNA by single base florescent extension of fixed, fragmented DNA strands.

Nanopore technology, such as Pacific Bioscience (PacBio, Menlo Park, CA) or Oxford Nanopore (Oxford, UK), can rapidly sequence full-length DNA, cDNA, and RNA. No cloning is involved. Single nucleotide strands remain intact and are rapidly pulled through small pores and sequenced by measuring the change in voltage. The drawback is reduction of base call accuracy, ranging from 85 to $95 \%$ (Greninger et al. 2015). Oxford Nanopore technology (ONT) was designed for sequencing portability and to be accessible to researchers with limited resources. The ONT device is pocket sized, portable, requires a flow cell for each run, uses simplistic sequencing reaction protocols, and is controlled by a laptop computer (https:// nanoporetech.com). The diagnostic potential and portability of ONT for "in the field" diagnostics was first demonstrated with human diseases during the 2014 Liberia Ebola outbreak (Hoenen et al. 2016; Kilianski et al. 2016). For plants, ONT has been used in sequencing of cDNA from tissue infected with bacteria and plum pox virus (Badial et al. 2018) and yam viruses (Filloux et al. 2018).

Bread wheat is grown in large areas throughout the U.S. Great Plains. Each year the wheat streak mosaic complex (WSM), including Wheat streak mosaic virus (WSMV), Triticum mosaic virus (TriMV), and High Plains wheat mosaic virus (HPWMoV), is responsible for an average of 5\% loss in production (Burrows et al. 2009). However, in 2017, the WSM complex accounted for 19.3 million bushels of lost production in Kansas, valued at \$76.8 million (Kansas Wheat Commission, 2017, http://kswheat.com/growers/ wheat-streak-mosaic-virus). Field WSM diagnosis is commonly confounded by the presence of Barley yellow dwarf virus (BYDV; Burrows et al. 2009). Until recently, genetic resistance to WSM was rare in wheat germplasm. This began to change with the varietal releases 
'Mace' (PI651043; Graybosch et al. 2009) and 'RonL' (PI648020; Martin et al. 2007) containing WSMV resistance genes Wsml and Wsm2 (Lui et al. 2011), respectively. Additional varieties with Wsm2 were released in the following years including 'Clara CL' (PI 665948; Martin et al. 2014), 'Oakley CL' (PI 670170; Zhang et al. 2015), 'Joe' (PI676270; Zhang et al. 2016), and 'Snowmass' (PI658597; Haley et al. 2011).

In 2015, 'Clara CL', a Wsm2 derivative of 'RonL', was found to have severe mosaic symptoms and stunting throughout a field in Hamilton County, KS. Immunological results suggested only WSMV was present in plant tissue. In 2017, three more sites in western Kansas, planted with Wsm2-containing lines, were identified with WSM-like symptoms and verified serologically to have WSMV. However, a confident diagnosis could not be made concerning other viruses. Based on the isolated occurrence of these symptomatic fields in relation to total state WSMV-resistant acreage, it was hypothesized that a new variant of WSMV has emerged which overcomes $W s m 2$. The possibility also existed that symptoms were due to a mixture of viruses or a new introduction of an unknown virus.

To test the hypothesis, the 'Clara CL' WSMV sample was initially sequenced using a classical approach of PCR, subcloning, and Sanger sequencing. Subsequently, new sequencing technology became available and was tested as means to diagnose wheat virus diseases. Here, we report the sensitivity of ONT to detect viruses in comparison with serological results, and the ability to construct complete genome sequences of WSMV, TriMV, and BYDV from field samples. Evidence is presented that lays a foundation for more accurate plant disease diagnostics.

\section{Materials and Methods}

Sources of infected tissue. In 2015, fresh plant tissue was isolated from 'Clara CL' exhibiting WSM-like symptoms in Hamilton Co., KS. In 2017, field plant samples, soft dough stage with little green tissue remaining, were collected from three more sites with WSMlike symptoms in Wsm2-containing varieties: 1) Hard white winter wheat variety 'Joe' plants from a field near Leoti, Wichita County, $\mathrm{KS}$; 2) 'Oakley CL' plants from a research plot visually rated to have 98\% WSM severity and 100\% plot infection at the Kansas State Research Station, Tribune, Greely County, KS; 3) 'Oakley CL' plants from a research plot rated at 10 to $20 \%$ infection at the Kansas State University Research Station near Weskan, KS, in Wallace County. Tissue was frozen at $-80^{\circ} \mathrm{C}$ until use. Control tissue was collected from the wheat variety 'Karl 92' (PI564245; Sears et al. 1997) infected with WSMV-MHK, a lab reference isolate. These plants were not vernalized and maintained at a constant vegetative growth stage growing in a greenhouse at $\sim 22^{\circ} \mathrm{C}, 16 \mathrm{~h} / 8 \mathrm{~h}$ day/night cycle. Infected tissue was harvested from the newest, most expanded leaf expressing severe mosaic symptoms.

Serological testing. Serological testing was performed to determine the presence of an infection by WSMV, HPWMoV, BYDV-PAV, Wheat spindle streak mosaic virus (WSSMV), and Soil-borne wheat mosaic virus (SBWMV). Test kits were not available for TriMV at the time of this experiment. Enzyme linked immunosorbent serological assay (ELISA) plates were prepared as per company recommendations with the following modifications. Plates were either incubated in a moist chamber for $4 \mathrm{~h}$ at room temperature or refrigerated at $4{ }^{\circ} \mathrm{C}$ overnight. Wells were washed $3 \times$ with $1 \times$ PBST buffer (Agdia). Symptomatic tissue, $0.2 \mathrm{~g}$, was sampled, placed in plastic mesh bags with $2 \mathrm{ml}$ of general extract buffer (GEB; Agdia), and homogenized. For each viral test, $100 \mu \mathrm{l}$ of two known positive samples in GEB, two negative samples in GEB, and $100 \mu \mathrm{l}$ of each sample homogenate were placed in the wells. The plate was then incubated in a moist chamber for either $4 \mathrm{~h}$ at room temperature or refrigerated overnight. Wells were then washed $8 \times$ with $1 \times$ PBST buffer. Alkaline phosphatase enzyme conjugate solution, $100 \mu \mathrm{l}(1 \times$ ECI buffer with corresponding enzyme conjugate; Agdia), was added to each well tested. The plate was then incubated in a moist chamber for $2 \mathrm{~h}$ at room temperature. Wells were then washed $8 \times$ with $1 \times$ PBST buffer. A PNP solution (1× PNP buffer with PNP at $1 \mathrm{mg} / \mathrm{ml}$; Agdia) was prepared and $100 \mu \mathrm{l}$ added to the test wells.
The plate was placed in a moist chamber, in the dark, and placed on an oscillating table at the lowest speed. After $1 \mathrm{~h}$ of incubation, the plate was removed from the moist chamber, the bottom of the plate cleaned with a paper towel, measured at $\mathrm{Abs}_{405}$ with a Biotek Model EL800 (Winooski, VT) plate reader. If the well's absorbance value was $3 \times$ the average of the negative samples, the sample was considered positive for the given virus.

cDNA preparation, sequencing, and assembly. One hundred $\mathrm{mg}$ of tissue was frozen in liquid $\mathrm{N}_{2}$, placed in a $1.5-\mathrm{ml}$ microfuge tube and ground to a fine powder with a plastic disposable pestle. Total RNA was isolated using the mirVana RNA Isolation kit (ThermoFisher, Waltham, MA) according to protocol with the total RNA option. For subcloning and Sanger sequencing, cDNA was constructed with $1 \mu \mathrm{g}$ of total RNA (260/280 of 1.6-1.9), $500 \mu \mathrm{M}$ XhoI-oligo$\mathrm{d}(\mathrm{T})_{20}$ primer, $100 \mathrm{mM}$ dNTPs, $5 \times$ first strand buffer, $0.1 \mathrm{mM}$ DTT, and $200 \mathrm{U}$ of Superscript RT II (ThermoFisher) and incubated at $50^{\circ} \mathrm{C}$ for $1 \mathrm{~h}$. Subclones of WSMV were made by cloning $0.75 \mathrm{~kb}$ $-1.5 \mathrm{~kb}$ segments of the viral genome using primers listed in Supplementary Table S1. PCR conditions were $25 \mu l$ reactions of $0.5 \mu$ l of the cDNA reaction, 10 pmole of each forward and reverse primer, $1 \times$ Taq buffer (Sigma-Aldrich, St. Louis MO), $2.5 \mathrm{mM} \mathrm{MgCl}_{2}$, and $1 \mathrm{U}$ of Taq polymerase (Sigma). PCR amplicons were cloned into pCR2.1 according to protocol (ThermoFisher), plasmids were purified using QiaPrep Spin Miniprep kit (Qiagen) and sequenced by Epoch Biolabs (Missouri City, TX). Sequencing reads were assembled using crossmatch/phred/phrap within MacVector (v16.0.8; Cary NC).

Full-length cDNA was created using the total RNA described above according to the protocol prescribed for the Oxford Nanopore Technologies 1D cDNA sequencing kit (SQK-LSK108; Oxford, England) with a few modifications. Two cDNA reactions were used: one using XhoI-oligo-d(T) ${ }_{20}$ for poly(A) viruses, and the other with random 6-mer primers (New England Biolabs, NEB, Ipswich, MA) for other RNA viruses. In a $13-\mu 1$ reaction, $250 \mathrm{ng}$ of total RNA (260/280 of 1.6-1.9) was mixed with $500 \mu \mathrm{mol}$ of either primer and $10 \mathrm{mM}$ dNTPs (NEB), heated at $65^{\circ} \mathrm{C}$ for $5 \mathrm{~min}$, then immediately placed on ice. Then $4 \mu \mathrm{l}$ of $5 \times$ first-strand buffer, $2 \mu \mathrm{l}$ of $0.1 \mathrm{mM}$ DTT, and $200 \mathrm{U}$ of Superscript RT II (ThermoFisher) was added. The mix was incubated at $50^{\circ} \mathrm{C}$ for $1 \mathrm{~h}$. Second-strand synthesis was completed by adding to the cDNA $10 \mu \mathrm{l}$ of NEBNext secondstrand synthesis buffer (NEB), $5 \mu$ l of NEBNext second-strand enzyme mix (NEB), $45 \mu$ l of nuclease free water and incubated at $16^{\circ} \mathrm{C}$ for $1 \mathrm{~h}$. The purification of DNA, end repair, and PCA adapter ligation were as described in the protocol. At the PCR step, $6.25 \mu l$ of dT-cDNA and $6.25 \mu \mathrm{l}$ of random 6-mer cDNA were mixed with $1 \mu \mathrm{l}$ of PCM, $25 \mu$ l of LongAmp Taq $2 \times$ Master mix (NEB), and $11.75 \mu l$ of nuclease free water. PCR was completed on a PTC-200 PCR machine (BioRad, Hercules, CA) with program of $95^{\circ} \mathrm{C}$ for $3 \mathrm{~min}$, and 18 cycles of $95^{\circ} \mathrm{C}$ for $1 \mathrm{~min}, 62^{\circ} \mathrm{C}$ for $1 \mathrm{~min}, 65^{\circ} \mathrm{C}$ for $11 \mathrm{~min}$, and a final extension of $65^{\circ} \mathrm{C}$ for $10 \mathrm{~min}$. Amplified DNA was purified using Qiagen PCR clean up kit. Five hundred ng of the cleaned PCR product was used for the remainder of the preparation, as described in the Oxford 1D cDNA sequencing kit (Oxford Nanopore).

Samples were loaded onto a MinION 107 v9.5 Flow Cell (Oxford Nanopore) and sequenced for various times. MinKNOW, with albacore v1.7.3 (Oxford Nanopore) was used for basecalling. Adapters were trimmed using porechop v0.2.3 (Wick, R, University of Melbourne), aligned to a cereal virus reference file, and consensus sequences were determined using CLC Genomics Workbench v11 (Qiagen). Nonwheat virus assemblies were blasted against the NCBI virus genome database (as of August 2017) using BLAST within CLC Genomics Workbench. Translations and ClustalW alignments were completed using MacVector v16 (Cary, NC).

\section{Results}

In 2015, tissue collected from 'Clara CL' wheat in Hamilton County, KS was tested and found positive for the presence of WSMV; however, other viruses were not detected based on ELISA immunological tests (Table 1). Primers specific to WSMV Sidney81 (AF057533; Stenger et al. 1998) were used to amplify WSMV 
fragments from across the WSMV genome. Fragments of the correct size (Supplementary Fig. S1) verified WSMV was present in the tissue. Initially, PCR amplicons were used for sequencing, which allows for the ascertaining of the population of WSMV within the

Table 1. Serological tests of wheat samples collected from four different counties in Kansas suspected to be infected with wheat viruses. Samples were tested for the presence of Wheat streak mosaic virus (WSMV), High Plains wheat mosaic virus (HPWMoV), Barley yellow dwarf virus - PAV (BYDV-PAV), Wheat spindle streak mosaic virus (WSSMV), and Soil borne wheat mosaic virus (SBWMV). As a control, one sample was taken from plants infected with a lab reference isolate of WSMV.

\begin{tabular}{|c|c|c|c|c|c|c|}
\hline \multirow[b]{2}{*}{$\begin{array}{l}\text { Location, } \\
\text { year }\end{array}$} & \multirow[b]{2}{*}{ Variety } & \multicolumn{5}{|c|}{ Serological result ${ }^{\mathbf{a}}$} \\
\hline & & WSMV & HPWMoV & $\begin{array}{l}\text { BYDV- } \\
\text { PAV }\end{array}$ & WSSMV & SBWMV \\
\hline $\begin{array}{l}\text { Hamilton } \\
\text { Co, } 2015\end{array}$ & $\begin{array}{c}\text { Clara } \\
\text { CL }\end{array}$ & + & - & - & - & - \\
\hline $\begin{array}{l}\text { Greely } \\
\text { Co, } 2017\end{array}$ & $\begin{array}{l}\text { Oakley } \\
\text { CL }\end{array}$ & + & + & - & - & - \\
\hline $\begin{array}{l}\text { Wallace } \\
\text { Co, } 2017\end{array}$ & $\begin{array}{l}\text { Oakley } \\
\text { CL }\end{array}$ & + & - & - & - & - \\
\hline $\begin{array}{l}\text { Wichita } \\
\text { Co, } 2017\end{array}$ & Joe & + & - & - & - & - \\
\hline $\begin{array}{l}\text { Lab } \\
\text { Reference }\end{array}$ & Karl 92 & + & - & - & - & - \\
\hline
\end{tabular}

${ }^{\text {a }}$ Sample was considered positive if the $\mathrm{Abs}_{405}$ value was $3 \mathrm{X}$ the absorbance for the plant negative control.

Table 2. cDNA sequencing results from Oxford Nanopore Technology MinION flow cells of virus-infected wheat samples. Adapters were trimmed and the reads were aligned to a set of 25 cereal viruses including High Plains wheat mosaic virus.

\begin{tabular}{|c|c|c|c|c|c|c|c|}
\hline \multirow{2}{*}{$\begin{array}{l}\text { Location, } \\
\text { year }\end{array}$} & \multirow[b]{2}{*}{ Variety } & \multirow{2}{*}{$\begin{array}{l}\text { Total } \\
\text { reads }\end{array}$} & \multirow{2}{*}{$\begin{array}{l}\text { Total } \\
\text { base } \\
\text { pairs } \\
\text { (Gb) }\end{array}$} & \multirow{2}{*}{$\begin{array}{c}\text { Avg. } \\
\text { read } \\
\text { length } \\
(\text { bp) }\end{array}$} & \multicolumn{3}{|c|}{ Average fold coverage ${ }^{a}$} \\
\hline & & & & & WSMV & TriMV & BYDV \\
\hline $\begin{array}{l}\text { Hamilton } \\
\text { Co., } 2015\end{array}$ & $\begin{array}{c}\text { Clara } \\
\text { CL }\end{array}$ & $\begin{array}{c}2.1 \\
\text { million }\end{array}$ & 2.4 & 1,158 & $1,284 \times$ & $600 x$ & - \\
\hline $\begin{array}{l}\text { Greely } \\
\text { Co., } 2017\end{array}$ & $\begin{array}{l}\text { Oakley } \\
\text { CL }\end{array}$ & $\begin{array}{c}1.1 \\
\text { million }\end{array}$ & 1.1 & 1,005 & $896 x$ & $162 x$ & $247 x$ \\
\hline $\begin{array}{l}\text { Wichita } \\
\text { Co., } 2017\end{array}$ & Joe & 760,226 & 0.810 & 1,066 & $374 x$ & $101 \times$ & $17.7 \times$ \\
\hline $\begin{array}{l}\text { Wallace } \\
\text { Co., } 2017\end{array}$ & $\begin{array}{l}\text { Oakley } \\
\text { CL }\end{array}$ & 157,798 & 0.113 & 721 & $18.1 \times$ & $4.3 \times$ & $8.6 x$ \\
\hline $\begin{array}{l}\text { Lab } \\
\text { reference }\end{array}$ & Karl 92 & 173,813 & 0.323 & 1,863 & $45.3 x$ & - & - \\
\hline
\end{tabular}

${ }^{a}$ Average fold coverage is based on the average number of times specific virus nucleotides are sequenced across the virus genome. tissue. Multiple peaks were present at numerous nucleotide positions, an indication of SNPs. However, on several occasions, dual peaks were at similar intensity. A consensus could not be made and IUPAC codes were used at these positions. Computer translation of these variable positions led to an ambiguous amino acid being called in the predicted protein (Supplementary Fig. S2). Attempting to draw consensus and clarify deletions, five plasmid clones were sequenced from each PCR segment. SNPs were verified at previous positions; however, two of the clones spanning WSMV nucleotide position 8311 contained an in frame 3 nt deletion and thus were considered one of the genotypes of the virus in the population. Two different viruses were assembled and designated as $\mathrm{KSHm} \_1$ and $\mathrm{KSHm} \_2$. KSHm_1 was 9,384 nucleotides from the $5^{\prime}$ untranslated region to the poly(A) tail and found to be $98.6 \%$ identical to WSMV Sidney-81 (Stenger et al. 1998). KSHm_2 is 9,381 nt long and is 98.5\% identical to WSMV Sidney-81.

In 2017, three more samples of infected wheat were obtained. Serological analysis was performed and WSMV was identified in the samples, while HPWMoV was only detected in the Greely County sample (Table 1). Sequencing was used to verify the ELISA results; however, ONT was used instead of Sanger. A single MinION flow cell system will have more than 1,200 nanopores available for single-strand sequencing and can run for $48 \mathrm{~h}$ on a laptop or office computer. Hamilton County sample cDNA was used for ONT sequencing, but only run for $24 \mathrm{~h}$. The remaining samples were sequenced with less run time to evaluate the sequencing completeness and detection sensitivity. Sample run times were 12,6 , and $2 \mathrm{~h}$ for Greely, Wichita, and Wallace counties, respectively. A laboratory reference, WSMV MHK, was sequenced for $2 \mathrm{~h}$.

A 24-h run of the cDNA from Hamilton County produced 2.1 million reads and a total of $2.4 \mathrm{~Gb}$ of data (Table 2 ) with an average read

Table 3. Nucleotide identity (\%) of virus isolates from sampled wheat tissues. Viruses were assembled and aligned using ClustalW to standard isolates. Columns represent isolates of wheat streak mosaic virus (WSMV), Triticum mosaic virus (TriMV) and barley yellow dwarf virus (BYDV), respectively.

\begin{tabular}{lccc}
\hline & \multicolumn{2}{c}{ Virus isolate used for comparison } \\
\cline { 2 - 4 } Tissue source & $\begin{array}{c}\text { WSMV } \\
\text { Sidney-81 }\end{array}$ & $\begin{array}{c}\text { TriMV } \\
\text { UN6-123 }^{\mathbf{b}}\end{array}$ & BYDV-PAV $^{\mathbf{c}}$ \\
\hline Hamilton Co. & 99.6 & 92.1 & - \\
Greely Co. & 99.6 & 92.2 & 95.0 \\
Wichita Co. & 99.5 & 92.2 & 79.4 \\
Wallace Co. & 99.4 & - & 93.7 \\
Laboratory reference & 99.5 & - & - \\
\hline
\end{tabular}

a AF057533, Stenger et al. 1998

${ }^{\text {b }}$ FJ263671, Fellers et al. 2009.

c EF043235, Beckett and Miller 2009, unpublished.

$940 \quad 960 \quad 980$

WSMV_Type_strain_AF285169 GACGCATCAAAGGACAT - - ACCAGAAG - - - A - TCT -CA - GAGGCTTTATC - AC - A - ACTTAT - - AG - T - GG - -C - G - TCA - TAC - A

Consensus GATGCCACAAAGGACAT - -ACCAGAAG - - -A -TTT - CA-GAGGCTTTATC - AC - A - ACTTAT - -AG -T - GG - -C - G -TTA - TAC-A Coverage

0 GATGCCAC - AAGGACAT - ACCAGAAG - - A-TTTCCA-GAGGCTTTATC-AC-AGCCTTAT--AG-T-GG- -C - G -TTA-TAC-A GATGCCACAAAGGACATGCACCAGAAG-- - ACTTTGCA-GAGGC--CATC-ACAA-ACTTATAAAG-TATG--C- - - -A-CAC-A GATGCCACAAAGGACAT - -ACCACAAG-- -A-TTT - CA-G-GGCTGT - CC-AC-A-AC--- -AG-T-GG- - C-G-TTACTTC-A GATGCCACAAAGGACAT - - ACCAGAAG-- -A -TTT - CA-GAGGCTTTAT---C-A-ACTTAT - -AG-T-GG- - C-G-TTA-TAC-A GATGCCACAAAGGACAT - -ACCAGAAG- - -A - T - T-TA-GAGGCT TTATCTAC-A-ACTTAT--GG-T-GG- - C-G-TTA-TAC-A GATGCCACAAAGGACAT - - ACCAGAAT-- -A - -CT - TT - ATGCCTTTATC-AC-A-ACTTAT - -AG-T- -G- -C -A - TGT -TAC-A GATGCCAC-AAGGACAT - - A-CACAAG-- -A-TTT - CA-GAAAC- -TATC-AC-A-ACTTAT- - AG-T-GG--C-A-T-- -TGCTA GATGCCACAAAGGACAT - - ACCAGAAG-- - A-TTT - CA - GAGGCTTTATC - AC - A - AC- - AT - - AG-T - GG - - C-G-TTA-TAC-A GATGCCAC-AAGGACAT - - ACCA-A-- - A-TTT - C-- -AGGCTTTATC-AC - A-ACTTAT - - GG - T - GC - - CACATTA - TAC - A GATGCCAC - AAGGACAT - - ACCAGAAG--- - GCT - -T - CAGGCTTTATC - AC - A - ACTTAT - - AG-T - GG- - C - C -TTA - TAC - A CA-ACATGGCAGACCAT - - -CCTGAAGTGTT - TAT - CA- -AGCCT TCAGC- - C - - -AGTTGT - - TGCA-GGTTC-G - GCA - CGC-A GATGC-T - AAAG-- - T - - TTTG - AG- - A - TTT - CA - GAGGCTTTATC - AC - A - ACTTAT- - AG - T - GG - - C - G - TTA - TAC - A GATGCCACAAGGGACAT--ACCAGAAG---A-TTTCCA-G-GGC--TATC-AC-A-AC-TATA-AT-T-GG--C-G-TTA-TAC-A
GATGC--C-AGCGACAT--ACCAGAAG---A-TTT-CAGGAGGCTTTATC-AC-A-ACTTAT--AG-T-GG--C-G-TTA-TAC--

Fig. 1. Illustration of the nucleotide variability within individual Oxford MinION sequencing reads from virus-infected Hamilton County wheat tissue cDNA against the genome of Wheat streak mosaic virus (WSMV) Type Strain (AF85169). Alignments are within nucleotides 932-996 of the WSMV genome. Alignment and visualization was performed by CLC Bioinformatic Workbench v11. 
length of 1,158 bases. From the other samples, total output ranged from 157,798 to 1.1 million reads and 0.113 to $1.1 \mathrm{~Gb}$ of sequence (Table 2). From each of the four field samples, WSMV and TriMV were detected and were the predominant species in the samples. BYDV-PAV was only detected in samples from Greely and Wallace counties. A BYDV-like virus was present in the Wichita County sample and was most closely aligned to BYDV-PAV. No HPWMoV cDNA was detected in any of the samples. When the noncereal viral sequences were compared with the total virus database, alignments to several bacteria phages were also found (data not shown).

Run times were compared with determined accuracy of virus species identification and variants. The 24-h sequencing run of the Hamilton County sample produced enough coverage of each virus to construct consensus genomes of WSMV and TriMV. Sequencing produced a WSMV coverage depth of 1,284×. Figure 1 illustrates some of the nucleotide sequence variability where each read represents a single variant of the in planta virus population. Despite this variation, a complete consensus genome could be assembled and was $99.6 \%$ similar at nucleotide level to WSMV Sidney-81. A $600 \times$ coverage was present for TriMV when aligned with TriMV U06-123 (Fellers et al. 2009) and 92.2\% identical (Table 3). ONT did have difficulty sequencing through the $5^{\prime}$ untranslated region of TriMV. From other county samples, accurate genomes could be assembled for WSMV, TriMV, and BYDV, except when coverage fell below $20 \times$.

The presence of a new variant of WSMV was a major question to be answered in this work. The WSMV nucleotide assemblies were aligned using ClustalW and compared with both Sanger sequenced WSMV and the WSMV Sidney-81 reference. A common nucleotide difference was found in the WSMV field isolates at position 6833 of Sidney-81 (Fig. 2A). After computer translation of the genomes and alignment, a total of 56 amino acid differences were found between the WSMV polyproteins. A common change was found at position 2235 (Fig. 2B). The field isolates either have substituted a valine $(\mathrm{V})$ or methionine $(\mathrm{M})$ for threonine (T). Assembled viral genomes have been submitted to GenBank, accession numbers MK31872-MK318281.

\section{Discussion}

Diagnostic virus detection has been dependent on several assays. Serological assays are based on the interaction of a polyclonal antibody recognizing a predominant virus protein, usually the coat protein. Immunological methods are quick and portable, but limited in sensitivity and only confirm the presence of a pathogen species. Viral titers can be estimated, but many of the antibodies are only effective at high titers. Plant samples in this work were tested following standard protocols within a plant disease diagnosis lab using commercially available immunological kits. WSMV was confirmed, inconclusive for BYDV, and had a single positive reaction for the presence of HPWMoV. Inconclusive results can come from sensitivity of the antibody, low titer, and a single reaction could be due to a false positive. No immunological detection kits were commercially available TriMV, although it is commonly found coinfecting with WSMV (Burrows et al. 2009; Fuentes-Bueno et al. 2011). ELISA has been the standard method of detection, although more sensitive assays have been developed for WSMV and TriMV using reverse transcription PCR (Price et al. 2010). Thus, based solely on the immunological assays, the only conclusion is that all samples contained WSMV. The tested wheat varieties were known to contain Wsm2 and should have been resistant to WSMV infection. Wsm2 is ineffective above $18^{\circ} \mathrm{C}$ (Seifers et al. 1995; Tatineni et al. 2016) and could have explained the infection; however, two samples were from isolated plots growing among other WSMV resistant lines. Also, a Wsm2 breaking WSMV variant has been isolated from foxtail (Kumssa et al. 2019).

To test the new variant hypothesis, Sanger sequencing was initially used to assemble a full-length sequence of WSMV from the Hamilton County sample. The process to isolate mRNA, PCR and clone $1-1.5 \mathrm{~kb}$ fragments, purification of either the PCR amplicons or clones, sequencing, and assembly of the virus took 6 weeks, yielding two unique full-length clones. Assemblies were based on 10 overlapping segments, and not full-length sequence. The deletion in KSHm_2 was present in a cloned fragment within the clone. The contiguous sequence in which the deletion was placed is not guaranteed to represent the actual viral genomic RNA strand. Despite these issues, both KSHm_1 and KSHm_2 appear to be new variants, but more samples were needed from different fields to determine the cause of the shift in virulence.

In the last few years, new portable sequencing technology has emerged allowing for the rapid sequencing of complete genomes, sequencing of metagenomes, phytobiomes, and detection of pathogens. ONT uses DNA strand, pull through technology to rapidly sequence complete and long DNA strands, without the need of cloning. In human pathology, ONT was used in the field to identify Ebola, Chikanguanya, and hepatitis C (Greninger et al. 2015). Pathogens were identified very quickly, even with a $24 \%$ error rate. When the flow cell was allowed to run for $6 \mathrm{~h}$, MinION produced enough sequence coverage that $90 \%$ of the Chikanguanya virus could be assembled at 97 to $99 \%$ accuracy (Greninger et al. 2015). ONT is also useful with RNA viruses. Ebola 3 and Equine encephalitis were identified $3 \mathrm{~h}$ after sampling (Kilianski et al. 2016). In the 2014 Ebola outbreak, ONT produced enough coverage depth to determine an error rate of $1.36 \times$ $10^{-3}$ (Hoenen et al. 2016).

In this work, ONT has been demonstrated to be more efficient than Sanger sequencing. From sample to diagnosis was 1.5 days.

\section{A WSMV S81 AF057533 WSMV MHK ONT ICT WSMV ONT WAL WSMV ONT GRE WSMV ONT HM WSMV ONT WSMV Hm_1 Sanger WSMV Hm_2 Sanger}

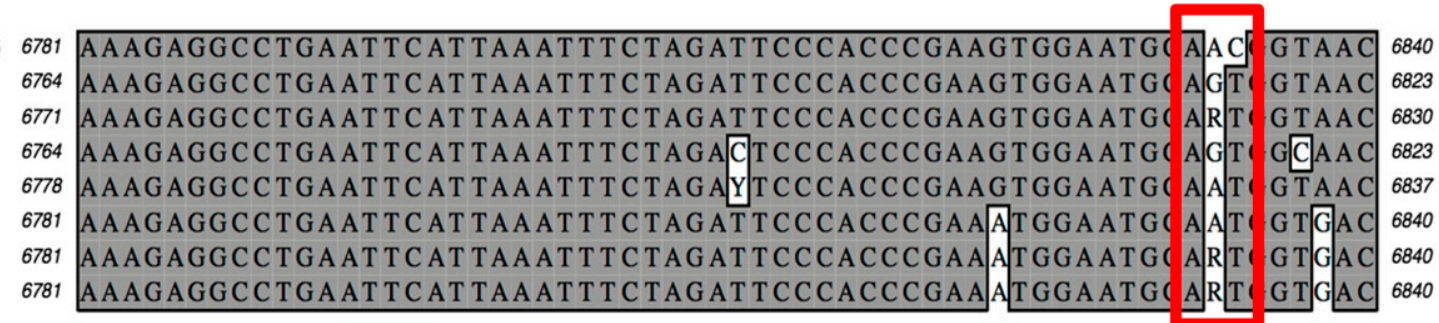

B WSMV Sidney 81 WSMV MHK ONT WAL WSMV ONT ICT WSMV ONT GRE WSMV ONT HM WSMV ONT WSMV HM_1 Sanger WSMV Hm-2 Sanger

Fig. 2. ClustalW alignments of (A) nucleotides and (B) amino acids of assembled Wheat streak mosaic virus (WSMV) variants found in infected wheat tissue against WSMV Sidney81 (AF057533). Red boxes highlight suspect changes in the viruses that may be the cause of virulence shifts in WSMV-resistant varieties. 
Diagnosis was accurate. The probabilities of correct alignments were $>\mathrm{e}^{-100}$ (data not shown) and complete genomes could be accurately assembled. Comparison between the Sanger and ONT Hamilton County samples showed $99.6 \%$ identity. ONT provided enough coverage depth to identify variation between genomes with high confidence. ONT can also be used to evaluate the complete population within the plant. Figure 1 demonstrates genome variability, as each read represents a single RNA strand. Granted, some of the variability is due to the inherent error rate of 9 to $15 \%$ per nucleotide strand read (Greninger et al. 2015). However, this can be overcome with depth of coverage. ONT can diagnose causal viruses in a short amount of run time. When different run times were compared, accurate virus species determination could be done in as little as $2 \mathrm{~h}$, but more sequencing is needed if variant detection is desired.

ONT proved useful to identify other viruses not detected by ELISA. TriMV was sequenced with enough coverage to determine a consensus genome within each plant sample. There was little variation within the TriMV plant population. The variation in TriMV of $92 \%$ identity (Table 3 ) is due to the lack of full-length sequence. The $5^{\prime}$ UTR of TriMV was more difficult to assemble, as many sequences terminated near the start codon in the cDNA. The $5^{\prime}$ UTR of TriMV is longer than most potyviruses and may have secondary structures (Fellers et al. 2009; Tatineni et al. 2009). BYDV-PAV and -GAV are the two major genotypes found in wheat producing areas of the U.S. Great Plains (Rotenberg et al. 2016). ONT was able to accurately identify BYDV-PAV within three of the samples. The full-length draft sequence assembled from $8.6 \times$ coverage from the Wallace County sample was enough for diagnosis, but not a genome consensus. The Wichita County BYDV isolate had the most divergent sequence, but was still most closely aligned with BYDV-PAV. A more specific primer for the $3^{\prime}$ end of the BYDV RNA during the synthesis of cDNA would be beneficial to get a complete genome.

In conclusion, these results demonstrate the potential utility of using ONT to identify viral disease in wheat field samples. Results revealed a near complete virus complement within the plant tissue. Viruses could be sequenced to enough depth of coverage to determine the predominant virus genotype within the tissue and provide possible variant evidence responsible for resistance breakdown. But, because of coinfection in these samples, a resistance breaking WSMV conclusion could not be made. Third generation sequencing is now providing a new avenue for disease diagnosis. This work can serve as a basis to develop protocols for field applications with smaller samples, more economical assays, and increased portability.

\section{Acknowledgments}

The authors thank Sean Muldoon and Dustin Deisher for their technical contributions to this work.

\section{Literature Cited}

Badial, A. B., Sherman, D., Stone, A., Copakumar, A., Wilson, V., Schneider, W., and King, J. 2018. Nanopore sequencing as a surveillance tool for plant pathogens in plant and insect tissues. Plant Dis. 102:1648-1652.

Burrows, M., Franc, G., Rush, C., Blunt, T., Ito, D., Kinzer, K., Olson, J., O'Mara, J., Price, J., Tande, C., Ziems, A., and Stack, J. 2009. Occurrence of viruses in wheat in the Great Plains region, 2008. Plant Health Prog. 10:14.

Fellers, J. P., Seifers, D., Ryba-White, M., and Martin, T. J. 2009. The complete genome sequence of Triticum mosaic virus, a new wheat-infecting virus of the High Plains. Arch. Virol. 154:1511-1515.

Filloux, D., Fernandez, E., Loire, E., Claude, L., Galzi, S., Candresse, T., Winter, S., Jeeva, M. L., Makeshkumar, T., Martin, D. P., and Roumagnac, P. 2018. Nanopore-based detection and characterization of yam viruses. Sci. Rep. 8: 17879.
Fuentes-Bueno, I., Price, J., Rush, C. M., Seifers, D. L., and Fellers, J. P. 2011. Triticum mosaic virus isolates in the Southern Great Plains. Plant Dis. 95: 1516-1519.

Graybosch, R. A., Peterson, C. J., Baenziger, P. S., Baltensperger, D. D., Nelson, L. A., Jin, Y., Kolmer, J., Seabourn, B., French, R., Hein, G., Martin, T. J., Beecher, B., Schwarzacher, T., and Heslop-Harrison, P. 2009. Registration of 'Mace' hard red winter wheat. J. Plant Regist. 3:51-56.

Greninger, A. L., Naccache, S. N., Federman, S., Yu, G., Mbala, P., Bres, V., Stryke, D., Bouquet, J., Somasekar, S., Linnen, J. M., Dodd, R., Mulembakani, P., Schneider, B. S., Muyembe-Tamfum, J., Stramer, S. L., and Chiu, C. Y. 2015. Rapid metagenomic identification of viral pathogens in clinical samples by realtime nanopore sequencing analysis. Genome Med. 7:99.

Haley, S., Johnson, J., Peairs, F., Stromberger, J., Heaton, E., Seifert, S., Kottke, R., Rudolph, J., Martin, T., Bai, G., Chen, X., Bowden, R. L., Jin, Y., Kolmer, J. A., Seifers, D., Chen, M., and Seabourn, B. W. 2011. Registration of 'Snowmass' wheat. J. Plant Regist. 5:87-90.

Hoenen, T., Groseth, A., Rosenke, K., Fisher, R. J., Hoenen, A., Falzarano, D. Marzi, A., Squires, R. B., Wollenberg, K. R., de Wit, E., Prescott, J., Safronetz, D., van Doremalen, N., Bushmaker, T., Feldmann, F., McNally, K., Bolay, F. K., Fileds, B., Sealy, T., Rayfield, M., Nicol, S. T., Zoon, K. C., Massaquoi, M., Munster, V. J., and Feldmann, H. 2016. Nanopore sequencing as a rapidly deployable Ebola outbreak tool. Emerg. Infect. Dis. 22:331-334.

Kilianski, A., Roth, P. A., Liem, A. T., Hill, J. M., Willis, K. L., Rossmaier, R. D. Marinich, A. V., Maughan, M. N., Karavis, M. A., Kuhn, J. H., Honko, A. N., and Rosenzwieg, N. C. 2016. Use of unamplified RNA cDNA-hybrid nanopore sequencing for rapid detection and characterization of RNA viruses. Emerg. Infect. Dis. 22:1448-1451.

Kumssa, T. T., Rupp, J. S., Fellers, M. C., Fellers, J. P., and Zhang, G. 2019. A new isolate of Wheat streak mosaic virus virulent to Wsm2. Plant Pathol. 68:783-789.

Lui, W., Seifers, D. L., Qi, L. L., Friebe, B., and Gill, B. 2011. A compensating Wheat-Thinopyrum intermedium Robertsonian translocation conferring resistance to Wheat streak mosaic virus and Triticum mosaic virus. Crop Sci. 51:2382-2390

Martin, T. J., Fritz, A. K., Seifers, D., and Shroyer, J. P. 2007. 'RonL' hard white wheat. Kansas Agricultural Experiment Station Publications, Kansas State University, Manhattan, KS.

Martin, T. J., Zhang, G., Fritz, A. K., Miller, R., and Chen, M.-S. 2014 Registration of 'Clara CL' wheat. J. Plant Regist. 8:38-42.

Price, J. A., Smith, J., Simmons, A., Fellers, J., and Rush, C. M. 2010. Multiplex real-time RT-PCR for detection of Wheat streak mosaic virus and Triticum mosaic virus. J. Virol. Methods 165:198-201.

Rotenberg, D., Bockus, W. W., Whitfield, A. E., Hervey, K., Baker, K. D., Ou, Z., Laney, A. G., De Wolf, E. D., and Appel, J. A. 2016. Occurrence of viruses and associated grain yields of paired symptomatic and non- symptomatic tillers in Kansas winter wheat fields. Phytopathology 106:202-210.

Sears, R. G., Martin, T. J., Hatchet, J. H., Cox, T. S., Bequette, R. K., Curran, S. P., Chung, O. K., Heer, W. F., Long, J. H., and Witt, M. D. 1997. Registration of 'Karl 92' wheat. Crop Sci. 37:628.

Seifers, D. L., Martin, T. J., Harvey, T. L., Fellers, J. P., Stack, J. P., Ryba-White, M., Haber, S., Krokhin, O., Spicer, V., Lovat, N., Yamchuk, A., and Standing, K. G. 2008. Triticum mosaic virus: A new virus isolated from wheat in Kansas. Plant Dis. 92:808-817.

Seifers, D. L., Martin, T. J., Harvey, T. L., and Gill, B. S. 1995. Temperaturesensitivity and efficacy of Wheat streak mosaic virus resistance derived from Agropyron intermedium. Plant Dis. 79:1104-1106.

Stenger, D. C., Hall, J. S., Choi, I.-R., and French, R. 1998. Phylogenetic relationships within the family Potyviridae: Wheat Streak Mosaic Virus and Brome Streak Mosaic Virus are not members of the genus Rymovirus. Phytopathology 88:782-787.

Tatineni, S., Ziems, A. D., Wegulo, S. N., and French, R. 2009. Triticum mosaic virus: A distinct member of the family Potyviridae with an unusually long leader sequence. Phytopathology 99:943-950.

Tatineni, S., Wosula, E. N., Bartels, M., Hein, G. L., and Graybosch, R. A. 2016. Temperature-dependent Wsm 1 and Wsm 2 gene-specific blockage of viral longdistance transport provides resistance to Wheat streak mosaic virus and Triticum mosaic virus in wheat. Mol. Plant Microbe Int. 29:724-738.

Zhang, G., Martin, T. J., Fritz, A. K., Miller, R., Chen, M.-S., Bowden, R. L., and Bai, G. 2016. Registration of 'Joe' hard white winter wheat. J. Plant Regist. 10:283-286.

Zhang, G., Martin, T. J., Fritz, A. K., Miller, R., Chen, M.-S., Bowden, R. L., and Johnson, J. J. 2015. Registration of 'Oakley CL' wheat. J. Plant Regist. 9: 190-195. 